\title{
Women's Wage Work: A Conference on New Directions for Research
}

\section{Susan Hirsch}

\section{Northwestern University}

On October 9 and 10,1981 a group of researchers and educators from the Midwest gathered at Northwestern University for a conference on "Women's Wage Work.' Northwestern's Program on Women sponsored the conference to bring together scholars, policymakers, and activists from a variety of disciplines and viewpoints to discuss major issues of women's wage work and to create an agenda for new research. Participants from the fields of education, history, industrial relations, sociology, and psychology addressed the questions of the dynamics of the sexual division of labor, the class structure of women's work, and the relationship of work and home.

Three papers presenting or evaluating new research on major female occupations in the United States-clerical work, nursing and teaching-formed the basis for discussing these issues. In "The Mutability of the Sexual Division of Labor: The Transformation of Clerical Work, ' Susan Hirsch, an historian at the Program on Women, noted that most research on this topic has been shaped by narrow conceptions of the supply of and demand for labor. In particular scholars picture technological change or proletarianization as causing feminization of the office, ignoring the larger context in which proletarianization of the factory and office occured simultaneously, the one remaining an arena for men's work, the other becoming one for women's. Hirsch suggested that further research on why feminization occurred in the office but not the factory could lead to a better understanding of the mutually supporting interaction of patriarchy and capitalism. In her comments, Judith Wittner, sociologist at Loyola University of Chicago, noted that the current wave of automation in the office reinforces the divisions of men's and women's office jobs by further degrading women's work.

Tim Diamond, a sociologist at Northwestern, examined the relationship of class and racial differences in the current transformation of nursing in "The Nursing Labor Force: Professionalization or Proletarianization.' Diamond noted that administrators blame nurses for the "nursing shortage," which is caused by mushrooming demand, and they pit professionalized RNs-predominantly white 
and U.S.-born-against an ever growing number of LPNs and nurses' aides-nonwhite and often from third-world countries. The concept of a shortage has become the rationale for proletarianization and for the exploitation of nurses' aides, who can be paid less than subsistence wages because they live in families with other low-wage earners or which qualify for welfare. Family structure and government policy thus provide a subsidy for capitalist enterprises. Kathleen Phillips, an educational psychologist at the University of Wisconsin-Parkside, commented that researchers need to examine women's subjective experience, how they name their oppression, in order to understand the impact of male capitalist and racist hegemonies in such instances as the current transformation of nursing.

In "Kitchens and Classrooms: Connecting Home and School in the Lives of Women Teachers," Dee Spencer Hall, a sociologist at Central Missouri State University, challenged the validity of the role concept in analyzing the behavior of workers. Noting that a role analysis perspective presumes that people compartmentalize their lives, she discussed how the work and home experiences of female teachers constantly interpenetrate. Commentator Lynne Miller, Assistant Principal of Riley High School, South Bend, Indiana, added that this analysis applies to male teachers as well, and that this refusal to compartmentalize one's life can form the basis for teachers' organization against oppressive working conditions. In a final session, presenters and participants discussed the implications of the issues raised in all three sessions for interdisciplinary research and for efforts to improve the lives of women wage workers. 